\title{
Antiplasmodial Test of Tinospora crispa Stem Extract against Plasmodium falciparum 3D7 Strain In Vitro
}

\section{Uji Anti Plasmodium Ekstrak Batang Tinospora crispa terhadap Plasmodium falciparum Galur 3D7 secara In Vitro}

\author{
Ihwan ${ }^{1}$, Muhaimin Rifa' 'i', Fitri $L E^{3}$ \\ ${ }^{1}$ Program Studi Pendidikan Biologi Fakultas Keguruan dan IImu Pendidikan Universitas Muhammadiyah Kupang \\ ${ }^{2}$ Program Magister Biologi Fakultas Matematika dan IImu Pengetahuan Alam Universitas Brawijaya Malang \\ ${ }^{3}$ Laboratorium Parasitologi Fakultas Kedokteran Universitas Brawijaya Malang
}

\begin{abstract}
This study aimed to prove the existence of anti-plasmodial activity from Tinospora crispa (T. crispa) stem extracts and to determine the $I C_{50}$ values as well as the best $T$. crispa stem extract concentration in inhibiting the growth of P. falciparum 3D7 strain in vitro. The degree of parasitemia was observed by counting the number of infected red blood cells in Giemsa stained blood films under a light microscope with a magnification of 1000x. The Plasmodium DNA concentration was measured using flow cytometryc with Propidium lodide (PI) staining. Analysis of fourier transform infrared (FTIR) spectrophotometer showed that the methanol extracts of T. crispa stem contained tinocrisposide compound. From the quantitative test results of Thin Layer Chromatography (TLC), it was obtained 0,22 \% alkaloids that might contain compounds of berberine and palmatine. One way ANOVA statistical analysis showed that the degree of parasitemia and the concentration parasite DNA of treatment group of dose of $2,0 \mathrm{mg} / \mathrm{m} /$ was significantly lower compared to the control group after 48 hours $(p=0,001)$ and 72 hours $(p=0,001)$ of incubation. The T. crispastem methanol extract has antiplasmodium activity, with $I C_{50}$ values between $0,27 \mathrm{mg} / \mathrm{ml}$ and $0,29 \mathrm{mg} / \mathrm{ml}$, and the effective dose to inhibit the growth of $P$. falciparum $3 D 7$ strain is $2,0 \mathrm{mg} / \mathrm{m} /$ with reducing parasitemia degree by $47,12 \%$ and $56,83 \%$ after 72 hours of incubation. From this study shown the methanol extract of T. crispastem was able to reduce the parasitemia degree of $P$. falciparum $3 D 7$ strain in vitro and could to be a potential candidate for anti malarias.
\end{abstract}

Keywords: Antiplasmodium, methanol extract, T. crispa, Plasmodium falciparum

\section{ABSTRAK}

Penelitian ini bertujuan untuk menguji adanya aktivitas anti plasmodium dari ekstrak batang $T$. crispa, dan mengetahui nilai IC $C_{50}$ serta konsentrasi ekstrak batang T. crispa paling baik dalam menghambat pertumbuhan P. falciparum galur 3D7. Derajat parasitemia diamati menggunakan mikroskop cahaya dengan perbesaran 1000x dengan cara menghitung jumlah sel darah merah yang terinfeksi melalui pengecatan Giemsa dan densitas DNA Plasmodium diukur menggunakan flow cytometri dengan pewarnaan Propidium lodium (PI). Analisis spektrofotometer fourier transform infrared (FTIR) menyimpulkan bahwa eksrak batang T. crispa mengandung senyawa tinokrisposid dan hasil uji kuantitatif Kromatografi Lapis Tipis (KLT) diperoleh 0,22\% alkaloid sehingga di dalam ekstrak tersebut diduga mengandung senyawa berberin dan palmatin. Hasil analisa statistik one way ANOVA menyimpulkan, kelompok perlakuan menunjukkan perbedaan yang signifikan dibandingkan kontrol, (nilai $p=0,000$ ) setelah inkubasi 48 dan 72 jam. Dapat disimpulkan bahwa ekstrak metanol batang T. crispa memiliki aktivitas anti plasmodium, dengan nilai IC $C_{50}$ sebesar $0,29 \mathrm{mg} / \mathrm{ml}$ dan $0,27 \mathrm{mg} / \mathrm{ml}$, dan dosis yang efektif untuk menghambat pertumbuhan $P$. falciparum galur 3D7 adalah 2,0 mg/ml dengan menurunkan derajat parasitemia sebesar $47,12 \%$ dan $56,83 \%$ setelah diinkubasi 72 jam. Pada penelitian ini diketahui, ekstrak metanol batang T. crispa mampu menurunkan derajat parasitemia P. falciparum galur 3D7 secara in vitro dan merupakan salah satu kandidat untuk pengobatan malaria.

Kata Kunci: Antiplasmodium, ekstrak metanol, T. Crispa, Plasmodium falciparum

Jurnal Kedokteran Brawijaya, Vol. 28, No. 2, Agustus 2014; Korespondensi: Ihwan. Program Studi Pendidikan Biologi FKIP Universitas Muhammadiyah Kupang, Jl. KH Ahmad Dahlan, No. 17, Kupang Nusa Tenggara Timur Tel. (0380) 833692 Email: ihwan.fkipbio@yahoo.com 


\section{INTRODUCTION}

Malaria is an infectious disease caused by Plasmodium parasite (Plasmodium falciparum, $P$. vivax, P. malariae, $P$. ovaleand $P$. knowlesi) that is naturally transmitted through the bite of female Anopheles mosquito (1). Until today, malaria is still to be the cause of high morbidity and mortality (2). Malaria parasite such as $P$. falciparum has been known to be resistant to anti-malarial drug such as chloroquine and sulfadoxine-pyrimethanime (SP) $(3,4)$. Due to the development of drug-resistance by the malaria parasitessince 2004, malaria eradication programs have not used chloroquine anymore as the primary drug for $P$. falciparum, World Health Organization (WHO) has recommended the use of combination anti-malarial drug containing artemisinin derivatives (Artemisinin-based Combination Therapy/ACT) (5).

The emergence of Plasmodium $s p$ resistance to antimalaria has encouraged researchers to look for new antimalarial drugs through research on plants that have been traditionally used by people to treat malaria. We investigated the usefulness of a traditional medicine Tinospora crispa (T.crispa), a climberplant commonly grown in the garden, locally called Brotowali. Tinospora crispacontain; alkaloid, soft resin, starch, glycosides, bitter substances, pikroretin and anti-malaria of quaternary alkaloid derivative in the form of berberine and palmatine. Tinospora crispaalso contains compounds such as glycosides furanoditerpen in the form of tinocrisposide $(6,7)$. Thus, it is supposedly able to suppress the development of Plasmodium. Previous study showed mice that inoculated with Plasmodium yoelii then treated with the crude extract of T. crispa at doses of $40 \mathrm{mg} / \mathrm{kg}$ showed a surprising and interesting result, one mouse from the group in which the dose of $80 \mathrm{mg} / \mathrm{kg}$ was administrated was still alive and the parasite was cleared from the blood stream (8).

\section{METHODS}

This study was conducted from September 2012 until July 2013 at Central Laboratory of Biomedicine, Faculty of Medicine, Brawijaya University. This study was an experimental study. The subjects used in this study were culture of Plasmodium falciparum divided into control group ( $P$. falciparum cultures without treatment), group that exposed by artemisinin $10^{-8} \mathrm{M}$ (an $\mathrm{IC}_{50}$ dose of artemisin in vitro) and groups that exposed by methanol extract of $T$. crispa stem with the dose of $0,5 \mathrm{mg} / \mathrm{ml}$, $1,0 \mathrm{mg} / \mathrm{ml}, 1,5 \mathrm{mg} / \mathrm{ml}, 2,0 \mathrm{mg} / \mathrm{ml}, 2,5 \mathrm{mg} / \mathrm{ml}$, and $3,0 \mathrm{mg} / \mathrm{ml}$ respectively, each of group was repeated 2 times (in duplicates well) (9).

\section{Preparation of Methanol Extract of Tinospora crispastem}

Brotowali (Tinospora crispa) was collected from its UPTD Materia Medica in Batu, the stems of T. crispa were minced into small pieces then dried in sunlight for a day and ground into powder with a traditional grinder. The powdered stem was macerated for 24 hours using $90 \%$ methanol solvent. Maceration process was carried out 3 times by replacing the methanol solvent every 24 hours, then evaporated and concentrated using N2 gas. Extract was made in the organic laboratory of Faculty of Mathematics and Natural Sciences of Brawijaya University, Indonesia.

\section{Preparation of Tinospora crispa Extract}

The methanol extract of $T$. crispastem was made as stock solution, $10 \mathrm{mg}$ extract was dissolved in $1000 \mu \mathrm{l}$ of RPMI 1640 medium (concentration of stock solution was 10 $\mathrm{mg} / \mathrm{ml})$. Then, it was added with $10 \%$ complete medium as a diluent to get the concentration of $0,5 \mathrm{mg} / \mathrm{ml}, 1,0 \mathrm{mg} / \mathrm{ml}$, $1,5 \mathrm{mg} / \mathrm{ml}, 2,0 \mathrm{mg} / \mathrm{ml}, 2,5 \mathrm{mg} / \mathrm{ml}$, and $3,0 \mathrm{mg} / \mathrm{ml}$. Dose of artemisinin used was $10^{-8}\left(\mathrm{IC}_{50}\right)$

\section{Antiplasmodial activity test of T. crispa extract}

Isolates of $P$. falciparum 3D7 strain was diluted and cultured in a medium containing the erythrocytes of $\mathrm{O}$ blood group with $5 \%$ hematocrit and $10 \%$ O blood group serum in the incubator with $5 \% \mathrm{CO} 2$ at $37^{\circ} \mathrm{C}$. Culture medium was replaced every day and culture was continued to obtain the degree of parasitaemia $>10 \%$. To test the antimalarial activity of methanol extract of $T$. crispastem, we put a $200 \mu$ l culture medium containing methanol extract of $T$. crispa stem with concentrations appropriate to treatment into sterile micro-plate (96 wells), each well contained $20 \mu \mathrm{l}$ malaria culture pellet and incubated for 48 and 72 hours. The thin blood smear was made by giemsa staining and observed under a microscope. Next, the number of erythrocytes infected by $P$. falciparum 3D7 strain parasite was counted in 1000 erythrocytes.Parasites Staining and Flow cytometric Analysis

Pellets was suspended in $1 \mathrm{ml}$ PBS containing $0,25 \%$ glutaraldehyde and incubated at room temperature for 20 minutes and centrifuged at $450 \times$ for 5 minutes. The pellet was washed using cold PBS 2 times. Cells were suspended in $0,5 \mathrm{ml}$ PBS containing $0,01 \%$ saponin and incubated at room temperature for 5 minutes and centrifuged at 450xg for 5 minutes. Then, the pellet was mixed with $40 \mu \mathrm{l}$ RNase $A$ and incubated in the dark at a temperature of $37^{\circ} \mathrm{C}$ for 40 minutes. The cells were suspended into $500 \mathrm{ml}$ propidium iodide and incubated in the dark at a temperature of $37^{\circ} \mathrm{C}$ for 60 minutes. Drug activity against malarial parasites was determined by measuring incorporation of PI. Flow cytometric data analyses were performed on a FACS caliber (Becton-Dinkinson) by using the CellQuestProprogram. Data were analyzed with normality and homogenity test. The statistical analysis was conducted using SPSS software version 20 with one-way ANOVA. If significant results were obtained, it would be conducted further testing using LSD. IC ${ }_{50}$ values analyzed using probit cuadratic analysis with SPSS software version 20 .

\section{RESULTS}

\section{Analysis of Tinospora crispa Anti-malarial Compounds}

Identification results of anti-malarial compound of furanoditerpen glycoside in the form of tinocrisposide using fourier transform infrared (FTIR) spectrophotometer can be seen in Figure 1.

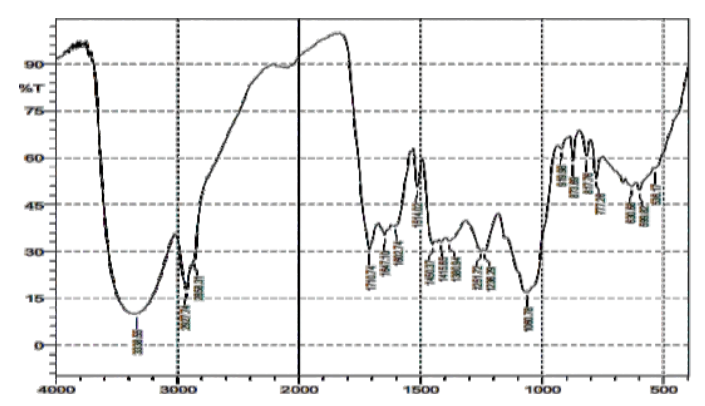

Figure 1. Infrared spectrum of methanol extract of $T$. crispastem in Potassium Bromide (KBr) pellet 
The data of infrared spectrum of methanol extract of $T$. crispastem (Figure 1) shows the absorption at wave number $3338,55 \mathrm{~cm}^{-1}$ suspected as absorption for the $\mathrm{OH}$ group, and the absorption at wave number region 2927,74 $\mathrm{cm}^{-1}$ suspected as absorption for the $\mathrm{C}-\mathrm{H}$ group and the absorption at wave number region $1710,74 \mathrm{~cm}^{-1}$ suspected as absorption for the ester $\mathrm{C}=0$ group.

\section{Parasitemia Degree of Parasite Culture}

The activity of methanol extract of T. crispa stem antiplasmodium was obtained by calculating the degree of parasitemia examined at 0 hour, just after T. crispa extract was exposed. Next, the degree of parasitemia was examined at 48 and 72 hours after the administration of $T$. crispa extract. The research results show that the degree of parasitemia for all treatments were lower than the positive control. The examination results of parasitemia degree are presented in Table 1.

The data in Table 1 below shows that over the observation time accretion (48 and 72 hours), it is followed by the average reduction trend in the degree of parasitemia. The results of one way ANOVA test showed a difference in the degree of parasitemia among groups with $p$ value of 0,000 , the results of statistical analysis of LSD indicated that after incubation for 48 hours, several treatment groups were significantly different compared to the positive control group $(p<0,005)$ and after 72 hours of incubation, all treatment groups showed significantly different compared to the positive control group $(p<0,005)$.

Table 1. The mean of parasitemia degree (\%) the methanol extract of $T$. crispa stem

\begin{tabular}{|c|c|c|c|}
\hline \multirow{2}{*}{ No } & \multirow{2}{*}{ Treatments } & \multicolumn{2}{|c|}{ Degree of Parasitemia } \\
\hline & & $\begin{array}{c}\text { Mean + SD (\%) } \\
48 \text { hours }\end{array}$ & $\begin{array}{c}\text { Mean + SD (\%) } \\
72 \text { hours }\end{array}$ \\
\hline 1 & 0 Hour & $11,18+0,57$ & $11,18+0,57$ \\
\hline 2 & Positive Control & $12,12+0,54$ & $13,55 \pm 0,45$ \\
\hline 3 & Artemisin $10^{-8}$ & $8,77+0,78^{*}$ & $6,24 \pm 0,13^{*}$ \\
\hline 4 & ET $0,5 \mathrm{mg} / \mathrm{ml}$ & $11,97+0,64$ & $10,66 \pm 0,39 *$ \\
\hline 5 & ET $1,0 \mathrm{mg} / \mathrm{ml}$ & $10,99+0,40$ & $10,79 \neq 0,03^{*}$ \\
\hline 6 & ET $1,5 \mathrm{mg} / \mathrm{ml}$ & $8,33+0,31^{*}$ & $8,27 \mp 0,56^{*}$ \\
\hline 7 & ET $2,0 \mathrm{mg} / \mathrm{ml}$ & $7,62+0,58^{*}$ & $5,85 \mp 0,54 *$ \\
\hline 8 & ET $2,5 \mathrm{mg} / \mathrm{ml}$ & $9,31+0,26^{*}$ & $9,03 \mp 0,20 *$ \\
\hline 9 & $\mathrm{ET} 3,0 \mathrm{mg} / \mathrm{ml}$ & $10,95+0,11^{*}$ & $10,11+0,36^{*}$ \\
\hline
\end{tabular}

Based on the data in Table 1 above, it can also be seen that treatment with methanol extract of T. crispa stem administration with the dose of $2,0 \mathrm{mg} / \mathrm{ml}$ provides the best result or the average degree of parasitemia was the lowest compared to other treatments with the percentage of parasitaemia degree equal to 7,62\% (48 hours) and 5,85\% (72 hours) with reducing parasitemia degree by $56,83 \%$ after 72 hours of incubation.

\section{Concentration of parasite DNA}

Flow cytometry analyzes using propidium iodide (PI) was conducted to determine the concentration of parasite DNA. Flow cytometry examination was conducted at 48 and 72 hours after treatment. The analysis results of flow cytometry are presented in Figure 2 and 3
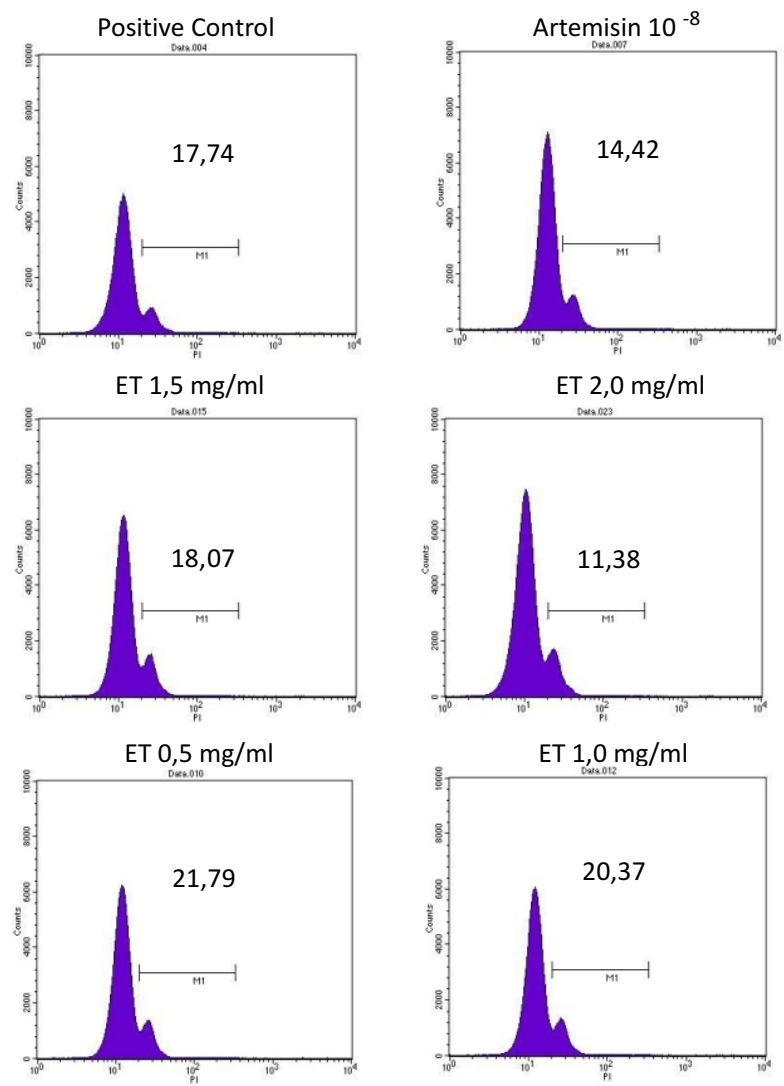

ET $1,0 \mathrm{mg} / \mathrm{ml}$

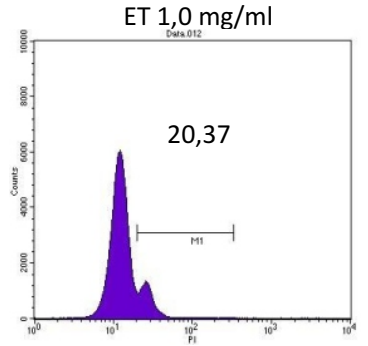

ET $2,5 \mathrm{mg} / \mathrm{m}$

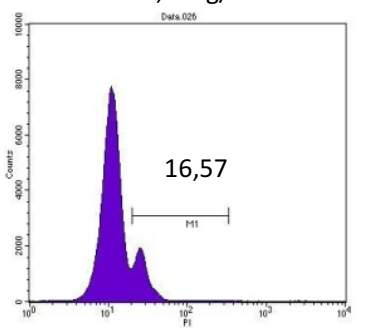

ET $3,0 \mathrm{mg} / \mathrm{ml}$

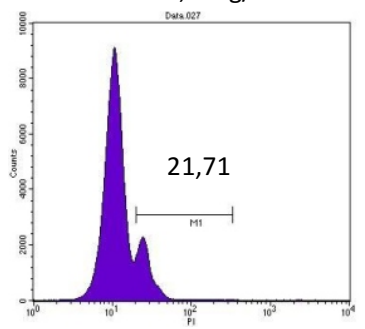

Figure 2. Concentration of parasite DNA as the results of analysis of flow cytometry $\mathbf{4 8}$ hours after treatment. Note : ET=Extract of Tinospora crispa

The research results showed that the concentration of Plasmodium DNA for all treatments were lower than the positive control. Treatment with methanol extract of $T$. crispa stem administration with the dose of $2,0 \mathrm{mg} / \mathrm{ml}$ provided the best result or the average DNA concentration was the lowest compared to other treatments with the percentage of DNA concentration equal to $11,38 \%$
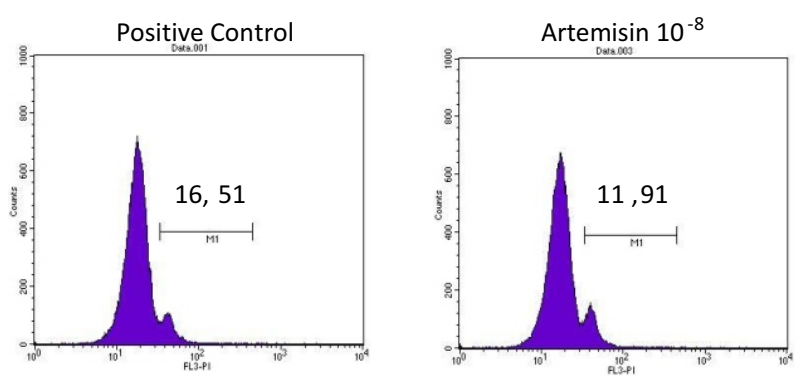

Figure 3. Concentration of parasite DNA as the results of analysis of flow cytometry 72 hours after treatment. Note: $E T=$ Extract of Tinospora crispa 


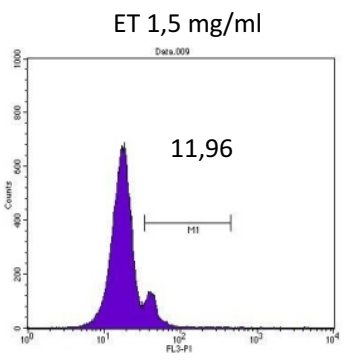

ET $0,5 \mathrm{mg} / \mathrm{ml}$

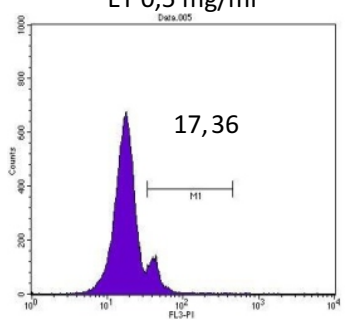

ET $2,5 \mathrm{mg} / \mathrm{ml}$

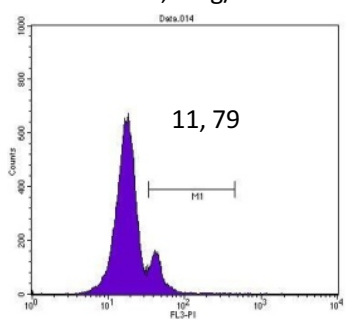

Figure 3. Concentration of parasite DNA as the results of analysis of flow cytometry 72 hours after treatment. Note: ET= Extract of Tinospora crispa. (Continued)

The research results showed that the concentration of Plasmodium DNA for all treatments were lower than the positive control. Treatment with methanol extract of $T$. crispa stem administration with the dose of $2,0 \mathrm{mg} / \mathrm{ml}$ provided the best result or the average DNA concentration was the lowest compared to other treatments with the percentage of DNA concentration equal to $8,73 \%$

Similar to the microscopic analysis, flow cytometric analysis results showed significant differences in mean DNA concentration among groups with the value of $p=0,002$ ( 48 hours) and the value of $p=0,000$ ( 72 hours). Of probit test results based on the observation of parasitemia degree using light microscope, it is obtained $I_{50}$ value equals to $0,29 \mathrm{mg} / \mathrm{ml}$, and of probit test results of concentration of DNA parasites based on flow cytometryc analysis, it is obtained $\mathrm{IC}_{50}$ value equals to $0,27 \mathrm{mg} / \mathrm{ml}$.

\section{DISCUSSION}

The identification of $T$. crispa above indicate the same pattern of absorption similar with the results of research conducted which is suspected as the absorption of $\mathrm{OH}, \mathrm{CH}$ and ester $\mathrm{C}=\mathrm{O}(7)$. It is supported by the statements that $\mathrm{OH}$ group absorption is in the range of wave numbers of $2700-3800 \mathrm{~cm}^{-1}, \mathrm{CH}$ group absorption is in the range of wave numbers of $2850-3000 \mathrm{~cm}^{-1}$ and $\mathrm{C}=\mathrm{O}$ group is in the range of wave numbers of $1600-1850 \mathrm{~cm}^{-1}(10)$. Thus, it might be that the methanol extract of $T$. crispa stem contains the antimalarial compounds of glycoside furanoditerpen in form of tinocrisposide.
Quantitatively conducted Thin Layer Chromatography test results indicate that the methanol extract of $T$. crispa stem contains alkaloid compounds equal to $0,22 \%$, in line with several studies concluding that $T$. crispa contains several alkaloid derivatives compounds such as aporfin, pikoretin, berberine and palmatine, pikroretosid tinocrisposide and triterpenoids $(11,12)$.

Reduction in the percentage of parasitemia degree of $P$. falciparum 3D7 equal to $47,12 \%$ and parasite DNA concentration to $56,83 \%$ after 72 hours of incubation parasite culture in the treatment of administration methanol extract of $T$. crispa stem is suspected to be caused by the active ingredient of $T$. crispa as an antimalarial compound form; berberine, palmatine and tinocrisposide. Similar research data were revealed by previous study using Plasmodium falciparum treated with the crude extract of Tinospora crispa at doses of $2,5 \mathrm{mg} / \mathrm{ml}$ showed reducing parasitemia degree equal to $100 \%$ after 72 hours treatment with methanol extract of T. crispa stem in vitro (9).

Berberine constitutes quaternary alkaloid compound, which is compound structure containing quaternary nitrogen which is known to be able to inhibit the growth of Plasmodium by blocking/inhibiting intracellular transport of choline (13). Choline compounds are required for phospholipid biosynthesis in the parasite membrane formation to close the parasitophorous vacuole, the cytosol and various subcellular compartement. Thus, inhibition of choline causes the failure of the formation of a new parasite. The choline transport blocking has been used as one of malaria treatment strategies (14). Berberine is an inhibitor of nucleic acids and proteins biosynthesis of $P$. falciparum, which is in vitro showed a strong interaction with DNA (15).Similar with berberine, palmatine also constitutes quaternary alkaloid compound and quinoline whose chemical structure only differs in their methoxyl and hydroxyl groups (16). Therefore, the two active ingredients are thought to have similar activities, mechanism, and inhibition target as antimalaria. According to tinocrisposide, it is a compound that has structure of glycosides furanoditerpen (7). This structure is similar to the structure of nimbolid compound that has the effect of antimalaria. Although up to recently, the inhibition mechanism of the two compounds on the growth of Plasmodium is still unknown, but due to the similarity of molecular structure between the two compounds, it is assumed that these two compounds have the same mechanism in inhibiting the growth of $P$. falciparum.

Neem seed extract contains antimalarial compounds of azadirachtin and nimbolid that are able to reduce the degree of parasitemia, and the number of $P$. falciparum hemozoin is better than chloroquine (17). It is also explained that although the mechanism of inhibiting the formation of hemozoin is unknown, it is suspected that nimbolid compound interact with heme such as artemisinin, due to the similarity between the molecular structure of artemisinin active substance (sesquiterpene lactone) and molecular structure of nimbolid compound (triterpenoid) (17).

Based on the average degree of parasitemia (Table 1 ) and the concentration of parasite DNA (figure $2 \& 3$ ), it can be seen that the inhibitory effect of $T$. crispa extract on the growth of $P$. falciparum tends to follow the magnitude of the dose, at doses more than $2.0 \mathrm{mg} / \mathrm{ml}$, an increase in the 
inhibitory effect is no longer visible, even tends to rise although still lower than positive control. Moreover, the correlation test results between the magnitude of T. crispa methanol extract dose and inhibition percentage and concentration of parasite DNA have no significant relationship. This phenomenon is expected because of the role of antioxidants contained in T. crispa. Brotowali (Tinospora crispa (L.) Miers), besides containing antimalarial compound, also contains antioxidant compound. A previous research showed that the ethanolic extract of brotowali stem has an effect as an antioxidant (18). Other research showed that brotowali plant contains flavonoid compound, epigenin, which has an activity as antioxidant (19). Antioxidant has an important role for parasite survival in particularly at high concentrations or under certain conditions.

Another possibility is the influence of metabolic enzymes. Tinocrisposide in small dose has not been able to induce metabolic enzymes so that it remains active against Plasmodium growth, whereas larger dose of tinocrisposide will stimulate metabolic enzymes, resulting in tinocrisposide compound that will be decomposed, oxidized or conjugated, thus, the anti malaria activity will be reduced or become inactive (7). It has been explained that it is predicted due to biphasic nature of tinocrisposide compound, of which the interaction with the receptor is not directly proportional to the concentration (20). It also may be due to the physical nature of tinocrisposide itself constituting a compound group of diterpene glycosides.

The artemisinin treatment group can reduce the parasitemia degree of parasite culture, it is presumably because the artemisinin is known to have the bridge structure of peroxide (C-O-O-C), which plays an important role in the mechanism of drug action. This peroxide bridge structure would bind to the ion $\mathrm{Fe}^{2+}$ (iron II ion) so that it breaks the bond of peroxide bridge and generates free radicals which are highly reactive, thus inhibiting and

\section{REFERENCES}

1. Singh B, Kim Sung L, Matusop A, et al. A Large Focus of Naturally Acquired Plasmodium Knowlesi Infections In Human Beings. The Lancet. 2004; 363(9414): 1017-1024.

2. World Health Organization. World Malaria Report 2011. (Online) 2011. http://www.who.int/malaria/ world_malaria_report_2011/en/. [accessed on Oktober 27, 2013].

3. Departemen Kesehatan Republik Indonesia. Pedoman Penatalaksanaan Kasus Malaria di Indonesia. Jakarta: Direktorat Jendral Pengendalian Penyakit dan Penyehatan Lingkungan; 2008.

4. Departemen Kesehatan Republik Indonesia. Pelayanan Kefarmasian untuk Penyakit Malaria. Jakarta: Direktorat Jendral Bina Kefarmasian dan Alat Kesehatan; 2008.

5. World Health Organization. Antimalarial Drug Combination Therapy. Report of a WHO Technical Consultation. Geneve, Swiss: Roll Back Malaria/World Health Organization; 2001.

6. Wijayakusuma HMH. Tanaman Berkhasiat Obat di Indonesia. Jilid I. Jakarta: Pustaka Kartini; 1992. modifying a wide range of molecules in the parasite cause the parasite dies (21). In addition, the mechanism of parasite growth inhibition by artemisin is due to the covalent bond between drugs and the parasite protein will damage the parasite membrane (22).

The use of single drug, including artemisinin, can lead to Plasmodium resistance on anti-malarial drugs. The use of artemisinin as a single drug is only weakening but not killing the parasites. To prevent this, WHO (World Health Organization) recommends the use of the antimalaria drug of artemisinin in combination with other antimalaria drugs through Artemisinin Combination Therapies (ACTs) method which has been shown effective to achievecure up to $95 \%$ (23).

The curve of parasitemia degree and the concentration of parasite DNA (the data are not shown) show that they are in line with the increase of observation time ( 48 and 72 hours), it is followed by the downward trend in the average degree of parasitemia and parasite DNA concentration although the correlation test results provide insignificant correlation.

Based on the results above, it can be concluded that the methanol extract of $T$. crispa stem has anti-plasmodium activity, with $I C_{50}$ value between $0,27 \mathrm{mg} / \mathrm{ml}$ and $0,29 \mathrm{mg} / \mathrm{ml}$, and the dose effective to inhibit the growth of P. falciparum $3 D 7$ strain is $2.0 \mathrm{mg} / \mathrm{ml}$ by decreasing parasitemia degree equal to $47,12 \%$ and DNA concentration to $56,83 \%$ after 72 hours of incubation. In this research, it can be concluded that the methanol extract of T. crispa stem is able to reduce the parasitemia degree of $P$. falciparum 3D7 Strain in vitro and could to be a potential candidate for anti malarias.

\section{ACKNOWLEDGEMENTS}

We thank to Yudha Ngatiril Lady for his technical help in culture and flowcytometryc analysis.

7. Adnan AZ, Gusmali DM, and Mukhtar $\mathrm{MH}$. Antimalarial Activity of Tinocrisposide Compound In Vivo. Cermin Dunia Kedokteran. 2001; 131: 27-31.

8. Rungruang $\mathrm{T}$ and Boonmars $\mathrm{T}$. In Vivo Antiparasitic Activity of the Thai Traditional Medicine Plant Tinospora crispa against Plasmodium Yoelii. The Southeast Asian Journal of Tropical Medicine and Public Health. 2009; 40(5): 898-900.

9. Najib Nik A Rahman N, Futura T, Kojima S, Takane K, and Ali MM. Antimalarial Activity of Extracts of Malaysian Medicinal Plants. Journal of Ethnopharmacology. 1999; 64(3): 249-254.

10. Silvesterstein RM, Webster FX, and Kiemle DJ. Spectrometric Identification of Organic Compounds. New York: John Wiley \& Sons; 1963.

11. Kresnady B dan Tim Lentera. Khasiat dan Manfaat Brotowali Si Pahit yang Menyembuhkan. Jakarta: Agromedia Pustaka; 2005; hal. 10-14.

12. Sukadana IM, Rita WS, and Koreh FR. Isolasi dan Identifikasi Senyawa Antimakan dari Batang Tumbuhan Brotowali (Tinospora Tuberculata BEUMEE). Jurnal Kimia. 2007; 1(2): 55-61.

13. Ancelin ML and Vial HJ. Quaternary Ammonium 
Compounds Efficiently Inhibit Plasmodium falciparum Growth In Vitro by Impairment of Choline Transport. Antimicrobial Agents and Chemotherapy. 1986; 29(5): 814-820.

14. Roshental PJ. Review. Antimalarial Drug Discovery: Old and New Approaches. The Journal of Experimental Biology. 2003; 206: 3735-3744.

15. Birdsall TC and Kelly GS. Berberine: Therapeutic Potential of an Alkaloid Found in Several Medicinal Plants. Alternative Medicine Review. 1997; 2(2): 94103.

16. Simanjuntak P. Tumbuhan Sebagai Bahan Aktif Antimalaria. Buletin Penelitian Kesehatan. 1995; 23(2): 1-11.

17. Aini N, Soebaktiningsih, Fitri LE, Kalsum U, and Sumarno. Pengaruh Ekstrak Biji Nimba (Azadirachta Indica) Terhadap Penurunan Derajat Parasit dan Jumlah Hemozoin pada Kultur Plasmodium Falciparum. Jurnal Kedokteran Brawijaya. 2004; 20(3): 115-124.
18. Chantong B, Kampeera T, and Sirimanapong W. Aktivitas Antioksidan Brotowali. (Online) 2008. http://www.actahort.org/members/showpdf?bookn rarnr=786_9 [accessed on Oktober 21, 2013].

19. Dweck AC and Cavin J. Andawali (Tinospora crispa)-a Review. Personal Care Megazine. 2006; 7; 1-3.

20. Adnan AZ, Husni M, and Almahdy A. Pemeriksaan Farmakologi Senyawa Furanoditerpen Glikosida Baru dari Brotowali (Tinospora crispa Miers). Warta Tumbuhan Obat Indonesia.1998; 4(2): 9-12.

21. Ridley RG. Malaria: To Kill a Parasite. Nature. 2003; 424: 887-889.

22. Nurachman $Z$ dan Putrianti ED. Artemisinin, Pembunuh Parasit Malaria. (Online) 2005. [accessed on September 11, 2011].

23. Departemen Kesehatan Republik Indonesia. Penghentian Monoterapi Artemisinin Mencegah Penyebarluasan Resistensi. (Online) 2006. http://depkes.go.id/index.php? $v w=2 \& i d=951$. [accessed on September 11, 2013]. 